\title{
Елена ДОЛИНСКАЯ
}

\section{ПАРАДОКСЫ ЭСТЕТИЧЕСКИХ СОВПАДЕНИЙ: АКАДЕМИК Н. МЕТНЕР И АВАНГАРДИСТ Э. ДЕНИСОВ}

Николай Метнер никогда ничего не писал об Эдисоне Денисове. Хотя бы потому, что они не встретились по датам жизни - Метнер уехал из России за восемь лет до рождения Эдисона. Так, может быть, Денисов, с его энџиклопедической образованностью и контрастами стилевых пристрастий, любил музыку Метнера и оставил о ней свои суждения? Этого никогда не было. Тогда есть ли основания к рядополаганию имен этих композиторов русской культуры, где один, представитель Серебряного века, творил в первую половину XX столетия, а второй стал лидером авангардных тенденџий во второй его половине? На наш взгляд, есть, если коснуться хотя бы некоторых, как показалось, в чем-то сходных установок двух композиторов. Например, обшеэстетических или языковых.

Материалом послужили важные тексты литературного наследия композиторов - «Муза и мода» Метнера, которую он писал в зашиту основ классического искусства, и «Записные книжки» Э. Денисова, что велись в 1980-е годы и где появлялись беглые заметки как о композиторских персоналиях, так и о разных сторонах языка музыки второй половины $\mathrm{XX}$ столетия. Изложение наших наблюдений структурировано в трех музыковедческих штрихах - $о$ современной музыке, о современных музыкантах, и о роли Света в музыке.

Начнем мы, однако, с маленькой интрады. Середина 1930-х годов. Париж.

Одна за другой появляются книги ведуших представителей русской музыкальной эмиграџии. В 1934 году «Моя жизнь» А.Т. Греченинова, в которой композитор рассказывает о начальном периоде своего творческого пути 1 . В 1935 - «Хроника моей жизни» И.ФD. Стравинского (на франџузском языке), также обрашенная к начальному периоду жизни композитора (до 1932 года). Здесь не только предстает череда событий, но и в значительной степени приоткрывается дверь в лабораторию творческой мысли Мастера. В том же 1935 году вышла из печати книга Н.К. Метнера «Муза и мода (в зашиту основ музыкального искусства)». Труд, однако,

\footnotetext{
1 Заметим, что именно желание осмыслить этапы пройденного пути часто заставляло деятелей культуры браться за перо.
} 
вовсе не автобиографический. Его направленность еще на этапе знакомства с рукописью горячо поддерживал С.В. Рахманинов. В письме Метнеру из Чикаго он писал: «Прочел ее в один присест и хочу вам высказать свои поздравления по поводу достижения Вашего на новом поприше. Сколько там интересного, меткого, остроумного и глубокого! И своевременно! Если даже болезнь эта пройдет как-нибудь, чего, признаюсь, я по-правде не вижу, останется навсегда описание ее, и какое удачное название Вы дали Вашей книжке! Вообще я вполне удовлетворен и с радостью напечатаю Вашу книжку, как только приеду в Европу. С нетерпением жду второй части!»1. Рахманинов не просто поддержал книгу Метнера, он опубликовал ее в своем издательстве «Таир».

Неудивительно, что ведушие представители русской музыкальной эмиграџии брались за перо в Париже, этой художественной Мекке Европы, в один исторический период. Разумеется, в их числе были и актеры, и художники, и писатели. В частности, И. Бунин, говоря о неизбывности ностальгии, справедливо заметил: «Россию, наше русское естество мы унесли с собой, и где бы мы ни были, мы не можем не чувствовать ее».

Хронологическое совпадение литературных трудов выдающихся деятелей мировой культуры ${ }^{2}$, в том числе отечественных, находящихся в эмиграџии, не требует объяснений - все они давно вступили в полосу творческой зрелости, а Париж сохранял свое лидерство как центр эмиграџии.

Штрих I. О современной музыке. Напомним, что в саморазвитии языка музыки минувшего века наряду с ведушей ролью расширенного типа мышления, его полисистемностью, имела место и очевидная исчерпанность авангардных звукоорганизуюших методов.

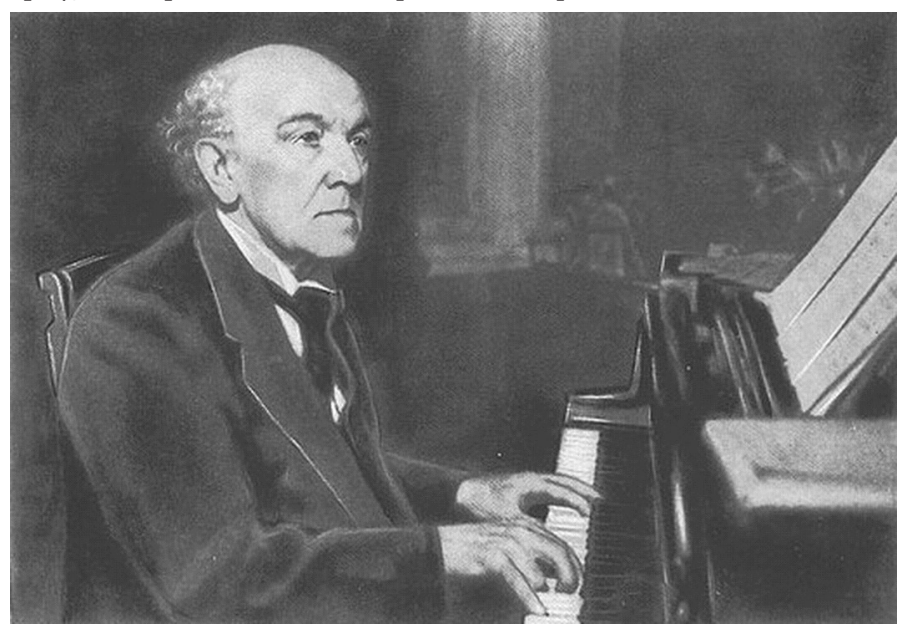

Николай Карлович

Метнер за ооялем (1940-е 22.)

\footnotetext{
${ }^{1}$ Письмо С.В. Рахманинова Н.К. Метнеру от 8 декабря 1934 года [4, с. 558].

${ }^{2}$ Сошлемся еше для примера на появление таких книг композиторов-исполнителей, как «Я - композитор» А. Оннегера или «Я - дирижер» Ш. Мюнша.
} 
В силу этого в эпоху постмодерна заявил о себе путь дальнейшего обновления - подключение атрибутики авангардных звукоорганизуюших принџипов к мажоро-минорному универсуму. Особый интерес приобретают отношение к первоэлементам, которые академик Метнер называл «первичными смыслами». Оставим в стороне декларированную непримиримость автора «Забытых мотивов» к проявлениям модификаџии музыкальной речи. Посмотрим на эту проблему с другой точки зрения и через, казалось бы, полярный круг суждениї, принадлежащих лидеру второй волны российского авангарда.

Денисов не принимал «леворадикальных» тенденций с их популизмом, упрошенчеством, тяготением к разным прототипам (в виде всевозможных нео-, ретро-, псевдо-, квази-). «Я не воспринимаю музыки, из которой изгнана красота», - утверждал он, считая главным достоинством музыки именно ее красоту. Композитор мыслил себя наследником романтической эстетики, а рассуждая о корнях своего творчества, говорил, что «вырос из Шопена». Причем Денисов необязательно мыслил само явление Красоты как разлив чувств. Облик новой Красоты ему виделся «в красоте мысли, как ее воспринимают, например, математики, или как ее понимал Бах и Веберн». Метнер, как известно, многократно писал о своей привязанности к тому, чтобы «чувство было осмысленным, а мысль прочувствованной».

Денисов не приемлет «минимузыки». Он утверждает также, что не воспринимает и такое широко

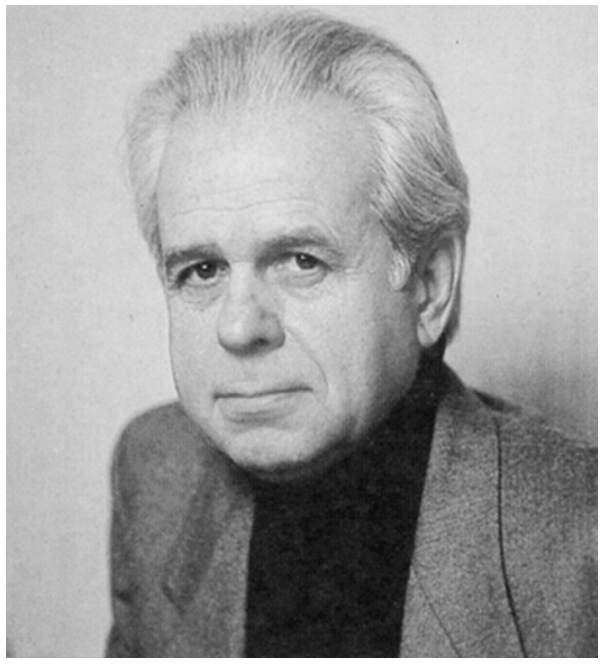

Эдисон Васильевич Денисов

распространенное явление, как полистилистика (термин А. Шнитке). Этот композиџионный метод он, по сути, считает спекулятивным и называет «одним из самых ярких свидетельств кризиса и деградаџии музыкального искусства» [5, с. 10].

Оставил Денисов суждения и о «Новой простоте»и «Новом романтизме»: «Это такие же пустые (и капитулянтские) течения, как и “мини-музыка”. Это все музыка для дураков (опять тот же блеф и одурачивание публики). Это течения неопасные (ибо они слабы и случайны), но очень вредные для традиџий в музыке (ибо они подменяют традиџию псевдотрадиџионностью)» [там же, с. 47].

$\mathrm{C}$ начала XX столетия Метнер говорил о первичных смыслах в музыке как о џентральных элементах ее системы. Почти через пять десятилетий Эдисон Денисов, уже став одним из лидеров отечественного авангарда, выдвигал близкие идеи. 
Мысли, высказанные в «Музе и моде», волновали Метнера постоянно, и не без воздействия его брата Эмилия, издавшего под псевдонимом «Вольфинг» книгу «Модернизм и музыка». При этом Николай Метнер не создавал собственную теоретическую систему. Его џель была иной зашитить и обосновать свою творческую позиџию в музыке, созданной гениями, прежде всего, немеџкой культуры (его кумиры - Бах, Бетховен, Моцарт, Шуман, Вагнер). Не получив законченного композиторского образования, но очень многое восприняв от Танеева, с которым некоторое время занимался, Метнер считал себя учеником Бетховена, с его идеальным равновесием эмоџионального и интеллектуального. С точки зрения Метнера, «простота бетховенских тем и гармоний давала возможность воспринимать бесконечную сложность построения формы (архитектоники)» [3, c. 26].

Зашишая основы классического искусства, Метнер многое фиксировал провидчески. В частности, такова его мысль, что в музыке нового времени не имеет место полное отвержение прежних норм языка. Здесь срабатывает иное - некая переменность функиий, т. е. пересмотр значений отдельных элементов музыкального языка, где некоторые, казавшиеся периферийными, оказываются способными к выдвижению на первый план, прежде всего, через индивидуальное отношение к ним современного композитора.

Штоих II. О современных музыкантах, или $О$ вкусах не спорят. Опираясь на наблюдения подобного склада, легко распознать глубинные смыслы рассуждений Метнера. Ему свойственны резко критические, нередко совсем необоснованные, субъективные нападки на џелый ряд композиторов, его современников. В их числе Регер, Р. Штраус, Стравинский, иногда Прокофьев. А вот последний не без гордости в своем Дневнике зафиксировал противоположное отношение к Николаю Карловичу. Прокофьев свидетельствовал, что его называли «чемпионом по исполнению фортепианной музыки Метнера».

Вместе с тем подчеркнем два важных обстоятельства: Метнер порой менял свое мнение о творчестве того или иного композитора, как это имело место, например, в связи с сочинениями С. Франка. Еше живя в России, он не распознал особой глубины, свойственной, скажем, камерным композиџиям последнего. В частности, знаменитая Скрипичная соната, посвяшенная Э. Изаи, поначалу не произвела на Метнера особого впечатления. Пройдет несколько лет, и в письме к А. Гедике Николай Карлович будет ему настоятельно рекомендовать изучить Симфонию Франка как сочинение, поразившее поэтичностью истинно симфонической конџепџии. Важно, что свой приговор тому или иному явлению культуры Метнер выносил после его тшательного изучения. Очень тепло относился он к Григу и вместе с А. Гедике приглашал его в Россию. Любовь же к Рахманинову была неизменной путевой звездой. Преклонялся Метнер перед Глинкой и Чайковским. Радовался удачным зарубежным постановкам «Бориса Годунова» И. Добровейном. 
О вкусах, однако, не спорят. В свой Пантеон Эдисон Денисов вводил Глинку, Моцарта, Шопена (у последнего ему особенно нравились баллады). Џенил песни Мусоргского, балеты Чайковского, был увлечен музыкой Рославџа.

Мишенями своей критики он избрал П. Хиндемита, а в более поздний период - Шенберга. Музыка Хиндемита уже в 1960-е годы была не просто не воспринята композитором. Он был весьма категоричен, утверждая, что «поставил на Хиндемите крест». В чем причина? Всего более Денисова раздражала в Хиндемите «неотобранность материала и отсутствие воздуха в его партитурах» [1, с. 15].

Не менее суров Денисов и в отношении к Шенбергу: «Мне Шенберг стал абсолютно антипатичен, и я не могу совсем его слушать - он для меня, повидимому, навсегда исчерпался. А его "тоники"1 поразительно тупы и неприятны и являются антиподами моим “тоникам" (которые часто выходят как Lux aeterna)»[там же, с. 11].

Шmpux III. О Свете. Денисов никогда публично не говорил о своей религиозности. Представитель точных наук, математик, он в конџе жизни раскрыл свою глубокую набожность: «Если бы я был свободен, я писал бы сейчас только о Боге» [там же]. Автор духовной оратории «История жизни и смерти Господа нашего Иисуса Христа» в одной из бесед признавался: «Дия меня вопрос веры и проблема
Бога - важнейшая часть человеческого существования» [там же]. Духовность для Денисова - понятие широкое: он считал, что все его сочинения в той или иной степени духовны, хотя и далеко не всегда связаны с религиозным текстом и сюжетом. Вера, которая одна и может спасти человека, в музыке у Денисова воплошается в устремленности к Свету, к обретению высшей Гармонии. Образ Христа появляется не только в Оратории, но и в Реквиеме (первая часть), в опере «Пена дней» (13 картина). Композитор писал: «Во всех томах, оставленных нам лучшими умами человечества гораздо меньше Истины, чем в самых простых словах Христа»².

Метнер пришел в жизнь глубоко веруюшим человеком. Посешение церкви всегда приносило ему радость, за исключением отдельных «модернизаџий» церковного чина в богослужебной зарубежной практике, что огорчало его искренне (как свидетельствуют письма композитора московской части семьи Метнеров-Гедике). Џерковные мелодии он включает в тексты своих конџертов (второй) и последнего сочинениязавещания - Фортепианного Квинтета. Это поистине знаковое произведение Метнер начал с открытием XX века, а завершил почти перед уходом. Почему же он не мог его так долго окончить? Метнер дописал свое сочинениезавещание тогда, когда нашел главную финальную идею - обрашение к Богу евангелическим «Блаженны алчущие

\footnotetext{
${ }^{1}$ Очень субъективные обвинения (например, якобы о тупости тонического трезвучия) Денисов распространял на Прокофьева и Пендереџкого.

${ }^{2} \mathrm{He}$ случайно, что (во взаимосвязи с религиозной приверженностью) композитор неизменно повторял: «Я не советский, я русский композитор».
} 
ныне, ибо насытитесь». На этих словах в музыке словно появляется Lux aeterna! Вспоминается наблюдение C. Слонимского о том, что композитор только раз в жизни может написать Квинтет и Реквием.

Как-то София Губайдулина затронула тему поистине таинственную. Она метафорически сказала, что «мы потеряли ночь». Звучит поэтично и весьма загадочно. И, несомненно, тонко. Но, право же, настолько, что уловить смысл можно с большим трудом. Вернее, каждый может прочесть формулу Софии Асгатовны посвоему. Мне гораздо ближе позиџия Романа Леденева, сказавшего, что «в искусстве XX века нами утрачен день, с его светлыми, живыми красками, ярким солнџем и прекрасной синевой неба. Наше небо - в тучах и облаках».

Образ Света у Денисова возникал нередко, как он говорил, через его собственные трезвучия (особенно ре-мажорные), которым придавал глубокий смысл. У тверждая, что «пожалуй никто (даже Моџарт) не обладал способностью дать такую жизнь трезвучиям, как Шуберт», Денисов также заметил: «У меня особый ре мажор. Такого ре мажора не было ни у кого» [1, с. 89, 97].

Завершим наши рассуждения сопоставлением мыслей Н. Метнера и Э. Денисова. Последний утверждал, что «Нет никаких приемов письма, которые бы “устарели”. В руках настоящего композитора все обретает иной смысл, все становится необходимым, логичным и оправданным» [там же, с. 107].

А разве не сходное суждение было одной из доминантных позиџй Метнера, сказавшего: «Тайна творчества, тайна индивидуальности там, где та же тоника и доминанта, та же каденџия, даже тот же оборот мелодии у двух авторов производит на вас разное впечатление» [3, с. 146].

\section{ЛИТЕРАТУРА}

1. Денисов Э. Исповедь. М.: Музиздат, 2009. 160 с.

2. Долинская Е.Б. Николай Метнер. М.: Музыка, 1966. 192 с.

3. Метнер Н. Муза и мода. Париж: Таир, 1935. 88 с.

4. Метнер Н.К. Письма / Сост. З.А. Апетян. М.: Советский композитор, 1973. $615 \mathrm{c}$.

5. Неизвестный Денисов. Из записных книжек (1980/81-1986, 1995). М.: Композитор, 1997. 157 с.

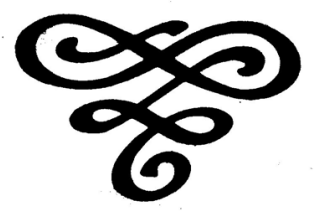

